\title{
Jews and Other Religious Confessions as Seen in the French Language Periodicals Published by the Huguenots in the United Provinces (1680-1715)
}

\author{
Michaël Green ${ }^{1}$ \\ (University of Cordoba, Spain / Jagiellonian University of Kraków) \\ e-mail: mi.gree@yahoo.com
}

Keywords: Huguenots, periodicals, early modern, Dutch Republic, Amsterdam, criminal

\begin{abstract}
Huguenots and Jews were both minorities in the United Provinces of the Netherlands. When the majority of the Huguenots arrived to the country, Jews had already resided there and had become part of Dutch society. The French newcomers, contrary to the Dutch, had little contact with the Jews and it was probably their first encounter with them. The majority of the Huguenots arrived there after the Revocation of the Edict of Nantes in 1685. Among the Huguenot refugees we find a certain number of intellectuals who established gazettes and journals. Those periodicals, published in French, open us a window in the perception that the Huguenots and the local Dutchmen had on the Jewish community and individual Jews, as well as on the Jewish nation as such. While journals refer to more scientific periodicals, the gazettes were collections of news and gossip both from the United Provinces and from other parts of Europe. The article focuses on the distinction between the different categories of Jews that appear in these periodicals and places them in the appropriate historical and scientific context.
\end{abstract}

\section{Introduction}

Interreligious and intercultural dialogue has many shapes and features, and can be traced in various historical occurrences. In this article, our focus is on the Huguenots, who having been persecuted for their faith, migrated to the United Provinces for mainly religious reasons. ${ }^{2}$ Coming from a country where only the Catholic religion was favoured - where Jews had already been expelled in 1306 - and arriving into a country which could be called 'tolerant', Huguenot intellectuals provide an interesting topic for examination with regard to the change in their perception of the Jews. Our goal in this article is to examine these Huguenot immigrants living in a country where various reli-

1 Fellow of the Foundation for Interreligious and Intercultural Research and Dialogue, University of Geneva. The scholarship was awarded by the Foundation for Interreligious and Intercultural Research and Dialogue (Geneva) for the postdoctoral fellowship program in the area of interreligious and intercultural dialogue, in collaboration with the University of Geneva, from September $1^{\text {st }} 2012$ to August $31^{\text {st }} 2013$. This scholarship and program was financed by the Levant Foundation.

2 Economic factors were also important in this migration, as was shown in the recently defended thesis of D. van der Linden, Experiencing Exile: Huguenot Refugees in the Dutch Republic, 1680-1700, Farnham 2015 . 
gious beliefs were tolerated, and to focus specifically on their attitude towards the Jews. Did they become more accepting towards Jews, who were not held in high regard in France? Our focus here is on 1680-1715, the years when there was mass immigration of Huguenots into the United Provinces of the Netherlands. As we will see below, within a generation they started to lose their Huguenot identity, and could no longer be seen as 'newcomers'.

The focus on intellectuals is not incidental, as it is mostly they who left written evidence of their views, as a result of their participation in the Republic of Letters and in non-scholarly press. Up to now, most of the research has focused on the views of Huguenot men of letters in relation to the Jews. An important book on the topic was published several years ago by Myriam Yardeni, in which several of the main Huguenot journals, such as the Nouvelles de la République des Lettres, Histoire des ouvrages des savans, and Bibliothèque universelle et historique, of Bayle, Basnage and Leclerc respectively were examined. ${ }^{4}$ The ambivalent attitude towards the Jews is shown throughout the book: while some elements of Huguenot views could be regarded as pro-Jewish, others had either a strong anti-Semitic character or at a milder anti-Jewish perception. In this article, I do not intend to argue against those conclusions, but to check whether this tendency can be seen in journals and gazettes of lower rank. Furthermore, modern scholarship distinguishes two kinds of Jews seen by early modern people, but is this really the case $?^{5}$ As we will see below, the attitude towards Jews was much more diverse than it might appear.

\section{Historical background: Huguenots and Jews}

It would be impossible to discuss our topic, and to understand the particular views of the Huguenots on other religions without some introduction into the four main elements of this article: Huguenots, Jews, the Republic of Letters, and periodicals in Early Modern Europe.

To begin with, let us briefly become acquainted with Huguenot history, which has been widely written and rewritten in the past thirty years, ever since 1985, which was the $300^{\text {th }}$ anniversary of the Revocation of the Edict of Nantes (1685). ${ }^{6}$ The Edict of Fontainebleau - which ended the rather relative religious freedom that the Huguenots, a Calvinist religious minority in France-enjoyed, symbolised an end of an era. Ever since the Reformation in the sixteenth century, France had been home to the followers of the Reform. Their situation varied: while at first they had been somewhat tolerated,

\footnotetext{
${ }^{3}$ On the Huguenot refuge see: Yardeni 1985; Yardeni 2002; Magdalene, Von Thadden 1985; Bots, Posthumus Meyjes (eds.) 1986; Greengrass 1985.

${ }^{4}$ Yardeni 2008. The book gives an excellent overview of the problem of anti-Semitism and anti-Judaism in the Early Modern period, as well as reflects on the contribution to this phenomenon by the views on Jews of Luther and Calvin. See also: Yardeni 1990; Yardeni (ed.) 1980; Yardeni 1977; Yardeni 1971; Yardeni 1997; Pater 1987; Grell (ed.) 1992.

${ }^{5}$ See for example: Deutsch 2012: 39-43, 115, 162-164, 11-13; Holmberg 2011: 11-13.

${ }^{6}$ On the Huguenots see, in addition to books mentioned in note 3: Labrousse 1985; Mentzer, Spicer (eds.) 2002 .
} 
towards the 1570 s their situation had deteriorated dramatically. The situation exploded in 1572 when, on St Bartholomew's Day, around 3,000 Huguenots were killed in Paris, following the order of King Charles IX. ${ }^{7}$ It was only in 1598, when Henry IV signed the Edict of Nantes, that the Huguenots were finally allowed to practice their religion under certain conditions (such as not to openly display their faith in Catholic towns). They were granted the right to have their own churches (outside the city centres and only in specific areas) and their own schools. By the late 1670 s and early 1680 s the antiHuguenot movement was clearly visible at court. Huguenots were losing their rights and political positions. Academies were closing down and many Huguenot scholars had to emigrate in order to make a living. ${ }^{8}$ In October 1685 , Louis XIV finally revoked the Edict of Nantes, and banned Huguenots from France. They were obliged to convert to Catholicism under the threat of death or a life-sentence to the galleys. Many Huguenots fled France to the neighbouring Protestant countries, with the biggest centres of Refuge being the United Provinces of the Netherlands, the German States and England. In the United Provinces, according to various estimates, the number of the refugees varied between fifty and a hundred and twenty thousand. ${ }^{9}$

The Dutch Refuge had several important centres, which were created by refugees of the first wave in 1572, long before the Revocation, and by subsequent immigrants who arrived throughout the seventeenth century. The most important centres were The Hague, Rotterdam, Leiden, Amsterdam and Utrecht. ${ }^{10}$ In the United Provinces, the Huguenots were received rather well, because they shared the Calvinist faith with the local population. The Dutch Reformed Church, though not an official church, had a privileged status. The situation of the Catholics was worse than that of the Huguenots, because they experienced more limitations on their daily lives. ${ }^{11}$ While most of the refugees were poor peasants, there were also nobles, lawyers, printers, scholars, religious ministers, traders and skilled craftsmen. Scholars, who are the focus of our interest in this article, became quickly engaged in religious polemics against the Catholics in France, but also published many books and articles on various subjects as part of their participation in the Republic of Letters, which we will discuss below. Most of the Huguenots were literate, because one of the Reformed principles was that everyone should be able to read the Bible. This means that they also had access to printed materials distributed in French in the United Provinces, and could actually read the ideas written by scholars and ministers. Within one or two generations of arrival, Huguenots were integrating into the local society, and losing their 'Frenchness', and the assimilation process continued from the early years of the seventeenth century. ${ }^{12}$

\footnotetext{
7 See: Jouanna 2015; Appleby 2007; Kingdon 1988.

8 On the economic reasons for the Huguenot emigration, see: Van der Linden 2015; Green 2015, chapter 2.

9 Frijhoff 2003; Yardeni 1985: 66.

${ }^{10}$ On the Huguenots in the United Provinces, see: Bots, Posthumus-Mejyes (eds.) 1986; Gibbs 1975: 255-287.

11 See: Parker 2008; Gelderblom, De Jong, Van Vaeck (eds.) 2004.

12 As asserted by Yardeni in her book (2002) Le refuge Huguenot.
} 


\section{The Jews in France and in the United Provinces}

The history of the Jews in France and in the United Provinces is well-documented and well researched. ${ }^{13}$ According to Bartley and Katznelson, in medieval France Jews lived mainly in the so-called 'royal domain', and financially supported the king. The authors claim they deflected "fiscal pressures to a widely disliked group", whom the king tolerated for his own benefit. Perhaps the most important fact about the history of Jews in France is the fact that between 45,000 and 120,000 of them were expelled by King Philip IV in 1306. ${ }^{14}$ Even though there were some Jews left in France particularly on its margins, most of the population had not seen a living Jew in their lifetime, as least those who lived in central and northern regions of France, as there were Jewish settlements (as "New Christians") in the south of the country. ${ }^{15}$ Therefore, the Huguenots too had little to no contact with Jews, until their arrival in the United Provinces. ${ }^{16}$

If the Jews were expelled from France in the Middle Ages, from late sixteenth century on they were allowed to settle in the Low Countries. The so-called 'New Christians', the Marranos of Spanish and Portuguese (Sephardic) origin, came to the United Provinces as Christians but then returned to their Jewish faith and formed a large Jewish community in Amsterdam. From early seventeenth-century onwards, they became a wealthy community of merchants, whose cultural and religious level was high. ${ }^{17}$

It is important to understand that there were two different populations of Jews in the United Provinces - besides the Sephardic Jews, there was also a large community of Jews coming from German territories that were joined by their Eastern-European brothers-the Ashkenazi Jews. Until late seventeenth century, the Sephardic Jews were much wealthier than the Ashkenazi, and they supported their poorer co-believers. In Amsterdam, originally, there was only one synagogue — a Sephardic one. Ashkenazi Jews who came to the city could not join the Sephardic community, but they were not prohibited from praying in the synagogue.

In the United Provinces, according to the historian Peter van Rooden, in the seventeenth century Jews were considered infidels by the Dutch. This was based on a reinterpretation of the Augustinian reference to the position of the Jews. Judaism was evaluated through a Christian prism of creed, with thirteen articles of Maimonides as its base. In Leiden there was even a university chair dedicated to fighting the Jewish misunderstandings of the divine word. Jews were to be pointed to their mistakes, and were not allowed to speak badly of the Christians. ${ }^{18}$ They had a separate status and were excluded from the political and social life of the United Provinces on many levels. They ceased to be treated differently in the second half of the seventeenth century, when other religious

13 Blumenkranz (ed.) 1972, and Bourdrel 1974, tell the history of the French Jews from the Middle Ages till the modern day; Blumenkranz, Dahan, Kerner 1975, is a bibliography of French Jewish medieval authors.

14 Barkley, Katznelson 2011: 475-476, 482.

15 See: Benbassa 1999.

16 Kaplan 2001: 21, 26-27. Kaplan speaks about the numerous Europeans who never saw a Jew, and Huguenots were surely no exception to this.

${ }^{17}$ For a rather broad overview of the situation of the Jews in the United Provinces, see: Israel, Salverda (eds.) 2002; Kaplan (ed.) 2008; Swetschinski 2000; Bodian 1997; Kaplan 1989: 23.

18 Van Rooden 2002: 136-138. 
dissenters became established, as Van Rooden refers to them, "communities with fixed boundaries." 19 In that sense, the dissenters were at that point treated as Jews, by imposing on them to take care of their own poor for example. ${ }^{20}$

Among the greatest limitations on Jewish life in the Netherlands, were the ban on Jews from joining guilds, the periodic bans on selling meat and alcohol to Christians and of course the limitations on settlement mentioned above. ${ }^{21}$ Nevertheless, the Dutch local authorities protected the Jews and they had autonomy in religious affairs. ${ }^{22}$ Sorkin states that " $[\mathrm{t}]$ he United Provinces' vaunted toleration was, to be sure, not the result of principled policy but of a pragmatic standoff between the political authorities who wished to maintain the parlous civil peace of a multi-religious society..." ${ }^{23}$ From 1654, the Jews of Amsterdam could obtain 'minor citizenship', though they were still banned from working as craftsmen and holding public office. ${ }^{24}$ By the early eighteenth century, the Jews had even begun participating in the political life of the Dutch Republic, and they were assisting the Dutch commercial success through their own networks of merchants across the world. ${ }^{25}$ Overall, the Jewish situation could be considered to be even better than that of the Catholics. ${ }^{26}$

In Amsterdam, for example, at the end of the seventeenth century, there was both a Sephardic and an Ashkenazi synagogue. The Sephardic synagogue was frequented by non-Jews who wanted to see what Jewish services look like. Kaplan asserts in his excellent study that the heads of the Sephardic community tried to project a "cultivated" image of the Sephardic Jewish community of Amsterdam to outsiders. He calls it a "theatre", in which the synagogue was a place where the gentiles came to observe the Jewish traditions and which had to deliver what these gentiles wanted to see. ${ }^{27}$ However, the two Jewish communities did not have particular liking for each other. While the Sephardic community were rich, well-mannered, well-aware of their position as 'guests' in a Christian land, and made explicit attempts not to provoke hatred against themselves from the side of the locals, the Ashkenazi community were poor, uneducated and ill-mannered. In the Sephardic eyes, the stereotype of the Ashkenazi and Polish Jews, or the so-called 'tudescos' and 'polancos' was very negative. Kaplan writes that their "image identified them with poverty and beggary, moral corruption and degradation, and even deviation from the ways of Judaism and the observance of the Torah". ${ }^{28}$ In Amsterdam, the local authorities issued rules forbidding the Jews to have any kind of personal relationship with Dutch women, and the heads of the Sephardic community enforced Dutch laws in order not to create any kind of confrontation that would worsen their position. ${ }^{29}$

\footnotetext{
19 Ibid.: 139-140, 142.

20 Ibid.

${ }^{21}$ Huussen Jr. 2001: 50, 53. In 1616, there was also a ban on speaking badly against Christianity. Ibid.: 46.

22 Ibid.: 51, 53.

23 Sorkin 2010: 249.

24 Ibid:: 251.

25 Israel 1989: 126-134; Huussen Jr. 2001: 51.

26 Van Rooden 2002: 143.

27 Kaplan 2001: 22-24, 26-27.

28 Kaplan 1989: 28-31, 39.

29 Kaplan 2001: 28-30.
} 


\section{The Republic of Letters and its scholarly journals}

In order to explain the background of our discussion on references to the Jews in the press, we should briefly refer to what in Latin was called Respublica Litteraria, or La République des Lettres, as it was known in French - the unofficial society of scholars in Early Modern Europe..$^{30}$ It originated in Italy in the late fifteenth century and reached its peak from the second half of sixteenth century to the end of the eighteenth century. The most important idea of the Republic of Letters was the exchange of knowledgethis was its primary goal. The name 'Republic of Letters' refers both to the means by which knowledge was transferred - by letters - and to the topics mostly associated with it: 'letters' as a discipline, including thereing all the humanities. In addition to letters, knowledge was exchanged by publications in books and in scholarly journals, such was Journal des sçavans, the first journal of its kind, published from 1664 onwards in Paris. ${ }^{31}$ The notion of a 'republic' meant that there was no official hierarchy-no monarchyand, theoretically at least, all 'citizens' of the republic were equal. Jews too took part in the Republic of Letters, and a good example of such participation is the Amsterdam Rabbi Menasseh Ben Israel (1604-1657), who participated in scholarly debates with such renowned scholars as Grotius, Vossius, Pierre-Daniel Huet, and Robert Boyle and whose works were known to many others, such as Isaac La Peyrère. ${ }^{32}$

Along with the French-published Journal des sçavans mentioned above, many similar journals appeared in the United Provinces thanks to the Huguenot intellectuals who had settled there. ${ }^{33}$ The most important and prominent were the Histoire des ouvrages des savans, edited by Henri Basnage, Nouvelles de la Republique des Lettres, edited by Pierre Bayle, and later by Jacques Bernard, and Bibliothèque universelle, edited by Jean Leclerc. ${ }^{34}$ Contributions to those journals were sent from across Europe, though mostly from northern and western Europe.

In addition to the scholarly journals, there were also gazettes, which were not scholarly, but informative in their contents. Gazette d'Amsterdam, Gazette d'Utrecht, and Gazette de Leyde, just to name a few, were published in the late seventeenth century in the United Provinces. Unfortunately, the gazettes were preserved much less than the journals and, unlike the journals, most of the surviving ones have not been digitised, which complicates the research process. ${ }^{35}$ The authors wrote to be published, and the published sermons, gazettes, and journals greatly influenced public opinion in the refugee community. ${ }^{36}$

${ }^{30}$ An excellent introduction to the topic of the Republic of Letters is written by: Bots, Waquet 1997.

${ }^{31}$ Bots, Waquet 1994.

32 Popkin 1987: 97; Littleton 2005: 5; Shelford 2007: 36, 153. More on Menasseh Ben Israel is in: Kaplan, Méchoulan, Popkin (eds.) 1989.

33 Bots 1997.

${ }^{34}$ On particular journals, see: Bots 1976; Bots, Van Lieshout 1984; Bots 1994.

${ }^{35}$ About the journals published in the United Provinces, see: Bots 1997.

36 Yardeni 2008: 143-154. 


\section{Methodology}

Here we will focus on seven journals and gazettes published by the Huguenots in the United Provinces between ca. 1680 and 1715, in order to examine their views on members of non-Christian religious communities in general, and on Jews in particular, with some reflections on Muslims and pagans. This topic has not been researched in depth, as the focus of much of the research effort has been on anti-Semitism in Europe, and there have been almost no studies on the views of the Huguenots outside France on other religions. To guide our examination, several questions should be posed. First, who were the Jews that the Huguenots related to in their journals and gazettes? Was there just one type of 'Jew'? Second, in which scholarly discussions were Jews referred to? Third, how often were Jews mentioned in the gazettes and how did the attitude towards them differ between journals and the gazettes? Lastly, could we say that the position of the Jews in those periodicals was different to the positions of Muslims and Pagans? To answer those questions, we will examine a selection of articles in the periodicals mentioned below for the years 1680-1715, focusing on the first years of publication. Moreover, we will need to examine not only the references in the journals and gazettes, but also the attitudes of individual editors, and the personal circumstances that influenced their choice of material, when those are known. The broader historical context will also be taken into account.

The scholarly journals that we are to examine are Journal littéraire, edited by Thomas Johnson, who himself was not a Huguenot, but had Huguenot correspondents writing for him; Histoire Critique de la République des Lettres, edited by the Huguenot Samuel Masson, and Nouveau Journal des sçavans, edited by Etienne Chauvin (later edited in Berlin). Alongside the journals, the non-scholarly gazettes examined are L'esprit de cours de l'Europe, edited by Nicolas Guedeville, and L'année burlesque ou recueil des pieces, que le Mercure a faites pendant l'Année 1683 and 1684, edited by Jean Crossnier.

\section{Scholarly journals}

As stated in the introduction, Huguenots in general were not particularly anti-Semitic. Myriam Yardeni even classifies the philosopher and journalist Pierre Bayle as one who should be "classer parmi les amis des juifs", if the criteria of the Enlightenment are to be applied, even though he also had sharp criticisms of the Jews. ${ }^{37}$ His contemporary, Jacques Basnage wrote L'Histoire et la religion des Juifs, which though very critical of the Jews (especially after they were exiled from the Land of Israel), cannot be seen as anti-Semitic. ${ }^{38}$ In her article, Miriam Silvera argues that Basnage even used some quotes from Ysaac Cardoso's Las Excelencias de los Hebreos in his book, sometimes even without reference..$^{39}$ Pierre Jurieu, a famous Huguenot theologian who lived in Rotterdam and was well-known for his Lettres Pastorales, wrote that Jews must have had

\footnotetext{
37 Yardeni 2008: 109.

38 Basnage 1706-1707. French titles and quotations are presented in their original autography.

39 Silvera 1991. See also: Elukin 1992.
} 
a great mission if they had been spared by God throughout their history and that they might be not as mistaken in their views as one might think. ${ }^{40}$

From these examples it might appear as if the Huguenots, in the United Provinces, were indeed much more tolerant towards Jews than Luther and Calvin had been. ${ }^{41}$ Myriam Yardeni writes that two of the most notable Huguenot figures of the Dutch Refugethe philosopher Pierre Bayle and the theologian Pierre Jurieu-focused some attention on the Jews. Bayle showed a rather dual perspective on Jewry, though he was mostly negative. ${ }^{42}$ At the same time, 'philosemitism' was clearly evident in Jurieu's work. ${ }^{43}$

Let us now look at and analyse several passages from the Nouveau Journal des sçavans, published in Rotterdam in 1694. The journal was edited by Étienne Chauvin (1640$1725)$, born in Nîmes. He was a religious minister, who immigrated after the revocation of the Edict of Nantes to Rotterdam, where he continued to exercise his profession, until he immigrated once more, in 1695, this time to Berlin. There he was appointed professor of philosophy. ${ }^{44}$ We will focus our analysis on the first volumes of his journal, which was published in the United Provinces.

Biblical Jews appear on several occasions in this journal. As early as the second volume, Chauvin writes abou the fact that Greece benefited from having many wise men: "C'est depuis la detention du people Juif en Babylone que la Grece s'est fait honneur de ses Sages". ${ }^{45}$ The discussion of the Seventy Weeks of Daniel also features a debate on the Jewish traditions of the Sabbatical year, which comes after six years of work is referred to in another article. ${ }^{46}$ It discusses the Hebrew language, or as the calls it the "langue Sainte", but even more importantly it features a discussion of Jewish history. ${ }^{47}$ Chauvin mentions in his review Conringe's claim that the Biblical Jews had no money-which they called shekels - or any other coins, and especially no coins with image of man on them, as it was forbidden to draw images of a man. ${ }^{48}$ Furthermore, he also discussed the idea that the ancient Jews lived in a theocracy, as mentioned by Conringe, because it was only God who could make new laws and grant privileges to people, and this situation lasted until God anointed Saul as the first King.

Up to this point, the tone is neutral, perhaps even friendly. In the next article, Chauvin turns to a much more sensitive point presented by the Catholic priest De Tillemont: that of Peter the Apostle and the Jews. Peter was Jewish and therefore was familiar with Jewish laws and tolerated them, which led Paul to reproach him. ${ }^{49}$ Peter is described as an

\footnotetext{
40 Yardeni 2008: 133-134.

${ }^{41}$ On the Age of Anti-Semitism, see: ibid.: 17-25, and specifically on Calvin: 26-43.

42 See: ibid.: 99-110.

43 Ibid.: 131-142. See also: Sutcliffe, Karp (eds.) 2011.

44 Alberti 1876, "Chauvin, Etienne".
}

45 Article III. "Johannis Lomejeri Zutphaniensis Dierum Genialium, sive Dissertationem Philologicarum Deca I. C'est-à-dire, Primiére [sic] Decade de dissertations Philologiques, que J. Lomejer a écrit en se divertissant dans l'étude des belles lettres. A Deventer, chez Albert Fronten, 1694. in 8. 26 feüilles", in: Nouveau Journal des sçavans (March-April 1694): 163-180, here 175.

${ }^{46}$ Eisenberg 2008, no pagination.

47 Article V. "Fasciculus Secundus Opusculorum", in: Nouveau Journal des sçavans (March-April 1694): 187-198.

48 Ibid: 192-194.

49 Article I. "Memoires pour server à l'Histoire Ecclesiastique des six premiers siecles", in: Nouveau Journal des sçavans (May-June 1694): 259-276, here 263-264. 
apostle of the Jews, who tolerated use of Jewish law in order not to alienate his followers. Paul did not accept Peter's separation of Jews and Christians and said that all should live according to the same laws - the laws of Jesus - and not Jewish law. ${ }^{50}$ Even more interesting is his description of De Tillemont's text about the supposed return of Paul to Jerusalem in the year 59 A.D. ${ }^{51}$

Chauvin, found De Tillemont "plein d'érudition" and reproduces the rather hard accusations he made against the Jews, portraying them as brutal, bloodthirsty murderers who had to be stopped by the Roman commander to save Paul's life. ${ }^{52}$ The story goes on to tell the story of how Paul was sent to Felix, Governor of Judea, who wanted to leave Paul in Jewish custody to please the Jews. ${ }^{53}$

Biblical Jewish history is discussed and debated in another book-review by Chauvin, this time a book of sacred history and philology by Willem Henricus Vorstius (d. 1652). ${ }^{54}$ In his review Chauvin notes a parallel drawn by Vorstius between Jewish and Catholic priests: both had to have a tonsure..$^{55}$ Eventually, the topic of the Jewish adoration of pigs and Bacchus comes up. ${ }^{56}$ This expression of 'false' accusation against the Jews, in this case Biblical, shows that Chauvin did not want any anti-Semitic feelings written in his journal. Moreover, it seems he chose to stress the pro-Jewish part of Vorstius's book.

Contemporary Jews do not escape the editor's attention either: Chauvin even mentions the Marranos, the new converts into Christianity, who had sought a safe haven in Narbonne in France, but had been forced to leave. ${ }^{57}$ In the same article he quotes a sentence in Hebrew, related to a 'Sicle' of Morin, with many typos: "שקל דוד כאשר פלם דוד ככאשר פלם בארצר ציוז בביה המקדש "כ, which shows that his own knowledge of Hebrew was not good.

Yet, some anti-Jewish thoughts still find their way into the journal. For example, while reviewing the book of D.T. Mémoires pour servir à l'Histoire Écclésiastique des six Premiers Siècles, the following passage is written by Chauvin while discussing Saint James the Older, son of Zebedée: "Herode Agrippa Roy des Juifs, [...] le fit mourir par l'Epée à Jerusalem, pour satisfaire les Juifs, à qui cette mort fût fort agréable" [Acts, $12: 2-3, \mathrm{MG}] .^{58}$ Here the Jews are presented as those who were punished for the execu-

${ }^{50}$ Paul addresses the Jewish Christians in Romans, 9-11, and writes about his mission to the gentiles in Gal. 2, and about the Jews killing Jesus in 1 Thes. 2.

51 Ibid.: 274-275. See also a discussion of this incident in: Fee, Hubbard Jr. (eds.) 2011: 602.

52 "Mémoires pour server à 1'Histoire Écclésiastique": 276.

53 Ibid.: 275.

54 Article XII. "Fasciculus Quatrus Opusculorim”, in: Nouveau Journal des sçavans (July-August 1694): 477-495.

55 “Fasciculus Quatrus Opusculorim": 488-489.

56 Ibid.: 490. There is also a reference in Petronius, a contemporary of Seneca, who says that Jews saw pigs as a god. See: Van Arkel 2009: 105. Flavius wrote that "the Jews united with the pagans in orgies of Bacchus". See: Flavius Josephus, 2008: 698. On Christian attempts of connecting between Jews and swine, as well as other anti-Jewish beliefs, see: Marshall 2006: 371-394.

57 Article V. "Dissertation Critique sur un des Anciens Sicles du Sanctuaire, envoiée à l'Auteur de ce Journal, par Monsieur D.L.B.P.”, in: Nouveau Journal des sçavans (September-October 1694): 544-551, here $549-550$.

58 Article VI. "Mémoires pour server à l'Histoire Écclésiastique des six Premiers Siècles, justifiez par les Citations des Auteurs Originaux. Avec une Chronologie, où l'on fait un abrégé de 1'Histoire Ecclesiastique et Profane; et des Notes pour éclaircir les difficultez desfaits et de la Chronologie. Par le Sieur D.T. [Louis Sebastien Le-Nain de Tillemont], Tome I. III Partie. Qui contient le reste des Apôtres, et S. Barnabé. 
tion of a Christian Apostle, and there is little doubt that such references would provoke negative sentiments towards the Jews. However, this reference is made based on a book written by a Catholic priest, and thus it reveals more about Catholic sentiments towards Jews than those of Calvinists. At the same time, the absence of any condemnation from the Huguenot editor shows that on this point he agreed with the Catholic argument.

All in all, in the Nouveau Journal des sçavans for the year 1694, we see numerous references to the Jewish people. There are too numerous to discuss them all, but the overall tone towards the Jews is mild, and even sympathetic. We see references to Biblical Jews, Jews exiled from Palestine, Marranos, and medieval Rabbis. Below we will encounter the same groups, and examine the views of other Huguenot editors.

The Journal Littéraire was edited between 1713-1737, though our focus will only be on the first two years of its publication. The editor of the journal was Thomas Johnson, a publisher from The Hague. In this journal, Dutchmen worked side by side with Huguenots, among them the famous Prosper Marchand and Pierre Desmaizeaux, who regularly contributed articles. Therefore, we cannot attribute each written article to a specific author, though it is clear that the Huguenot influence was very visible in the journal.

In comparison to the contributors to the Nouveau Journal des sçavans, those of the Journal Littéraire were less interested in biblical Jews and more interested in practical issues relating to Jewishness. This topic was discussed in a review of Albert Fabricius's Bibliographia Antiquaria..$^{59}$ In addition to the discussion of the Jewish antiquities, the Yerushalmi and the Babylonian Talmuds and the commentaries made on them by Christians, Fabricius refers to contemporary authors who wrote about the possibility that some native Americans might be of Jewish origin, particularly with reference to M. de La Créquinière's book Conformité des Coûtumes des Indiens Orientaux avec celles des Juifs, et des autres Peuples de l'Antiquité, published in Brussels in $1704 .{ }^{60} \mathrm{He}$ also mentions the book by the famous Sephardic rabbi of Amsterdam, Menasseh Ben Israel, printed in Amsterdam, where he argues that the remaining ten tribes of Israel are to be found in America.$^{61}$ No criticisms of the book or its opinions are expressed in the journal. According to Shalom Goldman, the seventeenth-century United Provinces were a fertile ground for various ideas related to the ten lost tribes of Israel, and Ben Israel's book was based on the testimony of Antonio Montezinos (Aaron Levi), who in 1644 reported to the Rabbi that he had found "the remnant of the Tribe of Reuben", and that some of the natives spoke to him in ancient Hebrew. ${ }^{62}$

The review of Fabricius's book is not the only article to mention Jews. Perhaps even more curious is another article in the same volume. In the 'Mandement' of the archbishop

\footnotetext{
A Bruxelles, chez Eugene Henry Fricx, 1694. in 12.16 feüilles”, in: Nouveau Journal des sçavans (May-June 1694): 418-427, here 419-420.

59 XV Article. "Jo. Alberti Fabricii SS. Theol. D. et Prof. Publ. Bibliographia Antiquaria, sive introductio in notitiam scriptorum, qui Antiquitates Hebraïcas, Graecas, Romanas et Christianas scriptis illustraverunt. Accedit Mauricii Senonenfis de S. Mifsae Ritibus Carmen, nunc primum editum. Hamburgi, et Lipsiae, impensis Christiani Liebezeit, Anno 1713”, in: Journal Littéraire, vol. 1, The Hague (May-June 1713): 160-172, in particular 162-164, and 168 .

${ }^{60}$ This book speaks of many aspects of the Jewish customs similar to the people of America. For overview of the Jewish-Indian "theory", see: Popkin 1989: 63-82.

61 The title of Ben Israel's book was in fact: מקוה ישראל, Esto es, Esperança de Israel, 1649-1650.

62 Goldman 1994: 17-18.
} 
Louis Antoine de Noailles (1651-1729), the editor writes that the cleric obeyed royal orders by connecting the deaths of the Dauphin and the Dauphine with the sins of the French nation. He says that "Dieu traite [the French] comme le Peuple Juif, parce que nous l'avons imité dans son impiété" ${ }^{63}$ Indeed, misfortune hit the monarchy in France, when two generation of the Bourbon family died within a year: Louis, the Grand Dauphin (1661-1711), his wife Marie Emilie de Joly de Choin and their son, Louis, the Petit Dauphin (1682-1712). Louis XV (1710-1774) eventually inherited the throne of his great-grandfather, Louis XIV, who died in 1715.

In this article, the Jews are presented as sinners who were abandoned by God. The reference to the Jews in this context could be linked to the Augustinian idea that Jews sinned against God and as a result were punished by losing their status and position. So who are the Jews that are referred to here? Surely not the Jews of the First Temple who were exiled because of the sins they committed against God, but the Jews of the Second Temple, who refused to accept Jesus and as a result lost independence and were exiled. Thus we have here, Jews of the second type: Jews after the fall of the Second Temple - the sinning exiled Jews. Though particularities are not necessarily important to us, it is clear that anti-Jewish sentiment was allowed in the Journal littéraire, even if the editors did not state explicitly whether they support these claims or not.

The final scholarly journal on which we will focus is Histoire critique de la République des Lettres, edited by Samuel Masson (d. 1742), which included mainly Huguenot contributors. ${ }^{64}$ Masson was a Huguenot, whose family first immigrated to England and then to the United Provinces ${ }^{65}$ His journal, as we will see below, was very much philosemithic and, among other topics, dealt with different aspects of Jewish influence throughout the ages.

Unlike the two previous journals, here the editor voices his opinion much more openly, and at times actually analyses the works that he reviews. For example, in "Passage de Pline, touchant l'Antiquité des lettres", Masson states that Mr. Ferrand, advocate at the Parlement of Paris concluded that the Hebrew letters are as old as the world. ${ }^{66}$ Plinius thought of the Assyrian letters as the oldest, but according to Ferrand, the 'Profanes' often referred to the Jews as Assyrians. Adam was the first man to invent letters. The editor opposes Ferrand, stating that Plinius could not have had Adam and the Jews in mind. He also challenges Ferrand's conclusion, which he reached based on Themistius's reference to the Assyrians as Jews by the prophanesim, as well as on his reference to Assyrian letters as Hebrew. ${ }^{67}$ In this case, however, Ferrand was right-he could not conclude that all the letters of Assyrians were always Hebrew. ${ }^{68}$ According to Eupolemus, Moses

${ }^{63}$ II Article. "Oraisons Funebres des Dauphins de", in: Journal Littéraire, vol. 1, The Hague (May-June 1713): 16-35, here 17.

${ }^{64}$ R. Granderoute 1991, Histoire critique de la République des Lettres (1712-1718), in: Dictionnaire des journaux 1600-1789, ed. J. Sgard, Paris, online edition: http://c18.net/dp/dp. php?no= 600 [accessed 8 September 2013].

${ }^{65}$ Couperus, "Samuel Masson (?-1742)".

${ }^{66}$ Parlement was a legislative and juridical body in Ancient Regime France. See: Daubresse 2005.

${ }^{67}$ Themistius (317-387) was a byzantine philosopher, who wrote among others commentary on Physics of Aristotle. See: Vanderspoel 1995.

${ }^{68}$ Article I. "Passage de Pline", in: Histoire critique de la République des Lettres, tant Ancienne que Moderne, vol. 1, Utrecht, Chès Guillaume à Poolsum (1712): 13-26, here 23-24. 
taught letters to the Jews, and they were passed on to the Phoenicians, and from them to the Greeks. Clement of Alexandria states that it was the "Grammatika" that was taught by Moses. ${ }^{69}$

If two Jewish-related articles are not sufficient to show Masson's pro-Jewish position, he comes up with a third one, in which he examines the life of King David and analyses Psalm 110. The editor argues that the works of the author should be examined together with his life. All of David's writings are sacred hymns. Even in antiquity chants were written for a reason. Therefore, the editor argues that the Psalms of David have to be seen in the context of their time. Would it not be enough that the Prophet King consoled Israel by frequent promises of the Messiah? The editor states that no, promises of the Messiah and spiritual kingdom alone would not be enough. It is important to know on which occasions the psalms were written. Masson sees however the Christian reason in David's life. God chose David and therefore the goal of the Vie de David is "instruire et edifier des Chrêtiens, à qui ces saints Cantiques doivent toûjours être précieux" ${ }^{70}$ For a Christian, the psalm is of interest because it refers to the Messiah and the New Testament. What is interesting for us is that Masson is familiar with Jewish authors, such as Joseph Kimchi (1105-1170), who was in his opinion "un des meilleurs Commentateurs Juifs". which appears twice in the sentence, as in one case it refers to God and in the other it refers to the King, and not to God and his son, Jesus Christ. ${ }^{72}$ Masson claims that the Jewish authors, including Eben Ezra and Kimchi, did not recognize the prophetic sense of the Psalm, and "c'est là leur grande erreur, qu'il falloit combattre". ${ }^{73}$

The tone of the article is very sympathetic towards the Jews and their scholarsthough in error, Masson still respects them and their knowledge. Here we see another type of Jews coming forward - the Jewish Rabbis who interpret the Bible. Those are in this case knowledgeable but in error, and this error has to be corrected.

In the second volume of Histoire critique de la République des Lettres, a very interesting subject arises. This discussion will continue in the following volumes: the relation between Hebrew and Chinese languages. ${ }^{74}$ The author of the anonymous dissertation,

${ }^{69}$ Ibid.: 25. See also a whole article on Epolemus: Article II. "Remarques sur Eupoleme", in: Histoire critique de la République des Lettres, tant Ancienne que Moderne, vol. 1, Utrecht, Chès Guillaume à Poolsum (1712): 27-42.

${ }^{70}$ Article III. "Essai d'une nouvelle Vie de David; ou Dissertation Critique sur le Pseaume CX", in: Histoire critique de la République des Lettres, tant Ancienne que Moderne, vol. 1, Utrecht, Chès Guillaume à Poolsum (1712): 42-94, here 44-49, 52.

${ }^{71}$ Ibid:: 72. On Joseph Kimchi, a Medieval Jewish commentator of the Bible, see: Gillingham 2008: 85-87. On Kimchi and his work, see: Kimchi 1919.

72 Gillingham 2008: 85-86.

73 "Essai d'une nouvelle Vie de David": 92. Abraham Eben (Ibn) Ezra (1089-1164) was a famous Jewish Sephardic Rabbi and scholar of the Bible and various sciences. See: Díaz Esteban (ed.) 1990; Sela 2003.

${ }^{74}$ Article 1. "Dissertation Critique sur le Pseaume CX ou Continuation de l'Article III du volume précedent", in: Histoire critique de la République des Lettres, tant Ancienne que Moderne, vol. 2, Utrecht, Chès Guillaume à Poolsum (1713): 3-64; Article III. Anonymous, [Ph. Masson] "Dissertation Critique, où l'on tâche de faire voit, par quelques exemples, l'utilité qu'on peut retirer de la Langue Chinoise, pour l'intelligence de divers mots et passages difficiles de l'Ancien Testament', in: Histoire critique de la République des Lettres, tant Ancienne que Moderne, vol. 2, Utrecht, Chès Guillaume à Poolsum (1713): 95-153. On European fascination with the Chinese culture and language, though without any reference to Masson, see: Porter 2001. 
who is identified in the next volume of the journal as Philippe Masson, the brother of Samuel Masson the editor, had interest in the Chinese language. ${ }^{75}$ The author claims that Chinese has similarities with Hebrew. It kept some of the original meaning of the Hebrew words that the author wants to restore to the Hebrew language. Hebrew, while it was a living language, suffered from the process that happens to other living languagesthe introduction of new words and abolition of old ones. Some words used at the time of Moses are not the same at the time of the Judges, and were not the same at the time of the first Kings. Some words had several meanings, which were lost, but they might be explained by Chinese, which it is claimed has some Hebrew roots. ${ }^{76}$ Philippe Masson even speculates on the essence of the Egyptian captivity of the Jews. He assumes that during their captivity in Egypt, certain Israelites probably studied Egyptian sciences, which they taught later in Hebrew to other Jews. According to him, King Solomon, whose numerous scholarly writings did not reach eighteenth century, probably also used a form of Hebrew that was different from the language of the Scriptures. ${ }^{77}$

Although he admires the language of the Bible, the author does not spare his criticism of the Jews, who are accused of losing the meaning of some words either through negligence or the length of time that had passed since the writing of the Holy Books, although they tried everything to preserve it. More than a thousand years had passed since Hebrew was a living language, and since the Jews had gone to Saturday Schools at the synagogues to learn it, in the same way that the Christians learn Latin and Greek today. ${ }^{78}$ At this point we see another type of a Jew emerging - the contemporary Jew, the negligent one, who does not care about the essence of Jewish tradition, does not care about the Holy language, and by his own carelessness allows this language to lose its sense.

The parallels between Chinese and Hebrew that the author of the article found might seem to modern researchers naïve and curious. For example, "מאו הארץ" haaretz, MG], is referred to the Chinese "min", which means people or nation. "מואב" [Moav, MG] turns to be "min av"-_from father" in the traditional translation. In Chinese however, "mo" means "without"-in this sense-fatherless (or illegitimate), which makes the Moavites bastards, illegitimate children. "יי" [yain, MG] means "wine" in traditional translation from Hebrew into English. In Chinese "yn" means "to drink, a drink", "ya"- “excellent", together—excellent drink. ${ }^{79}$

Philippe Masson goes on to criticise the traditional explanation of the word "טvפות" [totafot, MG], which is explained by the Talmudists in Sanhedrin, in accordance with their "wrong ideas". The important Jewish commentators, Rabbis Salomon Jarchi (Rashi) and Kimchi, sided with the Talmudists. Rashi explained that this word meant "two" in

75 Article II. Philippe Masson. 25 March 1713, Vliet. "Dissertation critique sur la Langue Chinoise, où l'on fait voir, autant qu'il est possible, les divers rapports de cette langue avec l'hebraïque; adressé à Mr. Reland, Professeur en langues orientales dans l'Université d'Utrecht" (footnote states it is same author as of the dissertation published in volume 2), in: Histoire critique de la République des Lettres, tant Ancienne que Moderne, vol. 3, Amsterdam, Chez Jacques Desbordes (1713): 29-106, here 29.

76 “Dissertation Critique, où l'on tâche de faire voit, par quelques exemples, l'utilité qu'on peut retirer de la Langue Chinoise": 96-99. The Chinese language to which the author refers is the Quon-hoa (Mandarine) language of the scholars and the court. Ibid.: 105.

77 Ibid.: 101.

78 Ibid:: 103-104.

79 'Dissertation Critique, où l'on tâche de faire voit, par quelques exemples, l'utilité qu'on peut retirer de la Langue Chinoise": 114-119. 
two ancient languages "Kafti" and "Africi". ${ }^{80}$ In Chinese, according to the author, "totafote" means "a study to get supreme happiness". ${ }^{81}$

This fascinating discussion on the Hebrew origins of the Chinese language continues in the third volume of the journal, also published in $1713 .^{82}$ Philippe Masson writes that because there is such a "wonderful harmony" and such similarities between oriental languages and Hebrew that there is no place to doubt that these languages have their origin in Hebrew. He refers to the professor of Arabic in Cambridge, the orientalist Edmund Castell (1606-1686) who, in the preface of his Lexicon Heptaglotton, states that a person who masters fully one of these languages, can master all the others. ${ }^{83}$ The author states that indeed, Chaldean, Syriac, Phoenician and Arabic are very close to Hebrew. Other languages are similar too to Hebrew in structure, in the way of speaking and in words. ${ }^{84}$

Chinese, according to Philippe Masson is one of them. Despite the opinion, common at the time, that Chinese did not resemble any other languages, Adam Preyelius published a book entitled Europae et Sinae admiranda (Frankfurt, 1656), in which he claimed that Chinese was actually very close to Hebrew in the shortness of the words. ${ }^{85}$ The author of this dissertation wants to disprove the previous assumptions, including those of two Jesuits - Gabriel de Magalhaes (Maggaillans in Masson's spelling), a missionary to China, and Louis le Comte - that there was no relation between Chinese and other languages. $^{86}$

There is discussion of Jewish-related topics in almost all the articles in the third volume. "Remarques critiques et theologiques sur les premieres paroles de Moïse", written by an anonymous minister in the United Provinces, most likely a Huguenot refugee, deals with the first word of the first book of the Old Testament "Bereshit". ${ }^{87}$ The author says that Jean Le Clerc, a renowned Genevan scholar and journalist, is completely wrong in his interpretation of those words on the first page of his first volume: Elohim bara ${ }^{88} \mathrm{He}$ says that Le Clerc thought that Jews and Moses adopted the plural form of "Gods" (Elohim) from the neighbouring pagans. But then, the author exclaims, Moses wrote his entire composition arguing against idolatry in sake of one God, therefore, how he could use its language?

כ"ח, ילקוט רש".

${ }^{81}$ Ibid.: 145-143. Rabbi Salomon Jarchi or Itzhaki, Rashi (ca. 1040-1105), French Jewish scholar and major commentator on the Bible. See: Kearney 2010; Doron 2010.

${ }^{82}$ Article II. Philippe Masson. 25 March 1713, Vliet. "Dissertation critique sur la Langue Chinoise, où l'on fait voir, autant qu'il est possible, les divers rapports de cette langue avec l'hébraique; adressé à Mr. Reland, Professeur en langues orientales dans l'Université d'Utrecht'. (footnote states it is same author as of the dissertation published in volume 2), in: Histoire critique de la République des Lettres, tant Ancienne que Moderne, vol. 3, Amsterdam, Chez Jacques Desbordes (1713): 29-106.

${ }^{83}$ Castell 1669. On Castell, see: Norris 1994.

84 "Dissertation critique sur la Langue Chinoise": 30-31.

85 The full title is: Adam Preyelius (1655), Artificia Hominum, Frankfurt on Main, in 12. Inner page of the book has the date 1656 .

${ }^{86}$ De Margaillans 1688: 84-107; L. Le Comte, "Lettre à Monseigneur 1'Archeveque Duc de Rheims, premier Pair de France. De la langue, des charactéres, des livres, de la morale des Chinois", in: Nouveaux Mémoires sur l'état present de la Chine, vol. 1, edition, Amsterdam (1696): 367-438, here 369.

87 Article III. "Remarques critiques et theologiques sur les premieres paroles de Moïse", in: Histoire critique de la République des Lettres, tant Ancienne que Moderne, vol. 3, Amsterdam, Chez Jacques Desbordes (1713): 70-84.

${ }_{88}$ The author of this article probably refers to the following book: J. Le Clerc (1710), Genesis sive Mosis Prophetae, $2^{\text {nd }}$ ed., Amsterdam: 2. 
To conclude this part, we see that overall the image of the Jews in Huguenot scholarly journals was rather positive. We see there were four main types of Jews: biblical, from the times of Moses, King David, and the latter Kings. While the first were considered holy people with a holy language, the Jews of the latter kings were already seen as sinners who were punished for not obeying God. The second type were the Jews of the time of the second exile up to the Middle Ages. They were once more sinners punished for their sins. The third type were their own contemporary Jews. They were almost never referred to in these scholarly journals except when talking about new publications. The last type were the Jewish Rabbis, who on the one had were considered an authority on Biblical issues and Hebrew, but on the other were accused of not preserving their language and of corrupting Jewish traditions. Therefore, we see that the scholarly journals presented an ambivalent attitude towards the Jews.

\section{Lay gazzettes}

After having discussed the scholarly journals, it is time to turn to "lay" gazettes, which reported daily news, anecdotes and so on. We will focus here on L'année burlesque ou recueil des pieces, que le Mercure a faites pendant l'Année 1683, edited by Jean Crosnier, and L'esprit de cours de l'Europe, edited by Nicolas Guedeville.

The gazette that has the most references to Jews is the L'année burlesque ou recueil des pieces, que le Mercure a faites pendant l'Année 1683, edited by Jean Crosnier (d. 1709). ${ }^{89}$ Crosnier probably had a criminal past and fled French justice to the United Provinces. He returned to France and in 1701 was imprisoned in the Bastille, dying eight years later. ${ }^{90}$ His sharp-tongued and perhaps even cheeky style reveals an interesting picture of the Jews in the eyes of their contemporaries and inter-confessional relationships between Jews and Christians. The gazette was comprised of short articles, divided according to the origin of the news that appeared in them.

We shall begin with a note supposedly sent from Amsterdam on 25 February 1683. It states as following:

Comme un avis tres salutaire,

Certain Juif et certain Chrêtien,

Qui ne sont pas fort gens de bien,

Sont priez de me satisfaire

Puisqu'on ne donne rien pour rien;

Sinon je declare et je jure,

Foy d'honneste et discret Mercure,

Que sans y manquer dans huit jours,

Ils recontreront leur peinture,

Au bout d'n Burlesque discours

The reference to "Certain Juif et certain Chrêtien, Qui ne sont pas fort gens de bien" is the first of quite a few that refer to rather problematic image the Jews had at the time. What is interesting is that both Jew and Christian are doing their deeds together, cooperating with each other.

\footnotetext{
${ }^{89}$ Crosnier (ed.) 1685a.

90 On Jean Crosnier, see: Sgard, "Jean Crosnier (?-1709)".
} 
A story of forbidden adultery — and above all with a Christian — is referred to in a note dated 20 May [1683], sent from Amsterdam — a "bourgeois de la Palestine", married his beautiful neighbour, who happened to have her period at that point, which forced him "sans en consulter les Rabinim" to look for consolation in the arms of a loyal Christian. It tells of a Jewish couple in Palestine, where a woman got her period, during which according to the Jewish law any sexual contacts are forbidden..$^{91}$ The good and law-abiding husband withdrew from his wife for ten days. At the same time, his imprudent wife committed adultery with a Christian. The article has a strong anti-Jewish sentiment, and of course the situation was also well known in Amsterdam.

As we read through the gazette, the stories become more frivolous: a note sent from Amsterdam on 7 October 1683 tells of another affair between a Christian man and a "paid" Jewish woman, who tells him that she is a Jew by religion, but Christian by love. This article presents three issues. The first is the question of the imprudence of Jewish women, where a Jewish prostitute offers her services to a Christian who, in a manner described as "brusque et rogue", is refused admittance to the Amsterdam synagogue. As Lotte C. van de Pol states, Jewish prostitution was a well-known problem in Amsterdam, while there were also many Jews who used the services of Christian ones. ${ }^{92}$ The refusal to enter the synagogue is a second problem. The third issue refers to the Jewish woman saying that that she is Jewish by religion but in love she is a Christian. As we saw above, the Sephardic community in Amsterdam made a considerable effort to show hospitality towards non-Jews who wished to pay a visit to their synagogue. ${ }^{93}$ Whether the author of this note tried to visit the Sephardic or the Ashkenazi synagogue is unknown, but his frustration from the refusal to be allowed in shows exactly why the Sephardim did their utmost to prevent such situations that would lead to displeasure of the "hosts", the local Dutchmen.

A year later, in 1684, another article is published. This time it is a male Jew who falls for a noble woman. ${ }^{94}$ This article cannot avoid comparison with one of the most important interdictions on Jews in Amsterdam - the ban on having any kind of sexual relations with Christian women. As we saw above, the heads of the Sephardic community in Amsterdam forbade their male youths from trying to get any attention from Dutch girls. ${ }^{95}$ This article shows that this problem was well-known and attracted public attention. The preventive methods of the community could not completely eliminate such events, despite the efforts made.

However, sexual misbehaviour is not the only thing related to unlawfulness of the Jews. Jewish criminal intent is shown in an article describing news from Amsterdam on $6^{\text {th }}$ July 1684 , where a story about Jewish thieves is presented, telling of their ruthlessness and desire to steal anything they can. According to Otto Ulbricht, overall rates of Jewish crime were no higher than for non-Jews. On the contrary, they were more often the victims of bodily harm than were Christians. ${ }^{96}$

\footnotetext{
91 On women and menstruation see: Wasserfall (ed.) 1999; Xervits (ed.) 2015.

92 Van de Pol 2001.

93 Kaplan 2001: 22-24, 26-27.

94 Crosnier (ed.) 1685 b.

95 Kaplan 2001: 28-30; Van de Pol 2001.

96 Ulbricht 1995: 52-53.
} 
While most of the descriptions of Jews are quite negative, one article, from $28 \mathrm{Au}$ gust 1684, refers to the abduction of the Jews in Padua and describes it as an atrocity, in particular referring to the women, who were abused without any respect for their age or status. In this notice, the author tells us that there was misinformation given in both Padua and Venice, based on which the Padovan crowd went to the Jewish quarter to burn all the people there..$^{97}$ The Jews looked for the protection of the Magistrate, but until it came, the crowd thinking that this violence served God, abducted many of them without respect for age or status. Though the language is used here is light, as in other notes in the gazette, the content is very negative against the offenders, while the Jews are looked at mercifully as innocent people being harmed by a fanatical crowd in the name of God. It seems that this event is related to the anger of the locals against the Jews who were falsely accused of helping the Turks in Buda and killing Christians. ${ }^{98}$

The gazette, L'esprit des cours de l'Europe, edited by Nicolas Guedeville (16521719), reported contemporary events in a serious manner, unlike the humoresque and ironical style of L'année burlesque. Guedeville was as son of a doctor, and was educated in a Catholic monastery. In 1688, he left the monastery and came to Rotterdam where he converted to Calvinism. ${ }^{99}$ In the volume of August 1699, in a section dedicated to the French court, the following notice appeared regarding the conquest of America: "Le droit de Conquête n'est-il pas bien établi? on pretend même que Dieu en est le fondateur, et que sans cela les Israëlites n'aurient été qu'une Troupe de voleurs quand ils prirent possession de la terre promise". ${ }^{100}$

In this passage, the Guedeville states that there are some people who claim that it was God who was the origin of the right of Conquest by allowing the Israelites to conquer the Land of Israel, as without his permission they would only be a gang of thieves stealing someone else's property. From the text, it is clear that Guedeville does not agree with this justification, but neither does he include Jews in the category of criminals nor deny their right to live in the Land of Israel. However, the stereotype of "thieves" he presents in his article, is an interesting indication of the opinion on Jews at the time.

In the same month, a large notice on the Polish court, and its "Pacta Conventa", refers to the anti-Jewish demands brought up before the polish Diet and King Augustus II: along with Lutheran, Calvinists, Jews were to be banned from Duchy of Moscow and Warsaw. ${ }^{101}$ Guedenville writes that these demands were not pacifistic, but provides no further indication of his attitude towards this issue.

Overall, the Jews are much less prominent in these gazettes than in the scholarly journals, but we get much more information about the Ottoman Turks, who were besieging various places in Europe at the end of the seventeenth and start of the eighteenth centuries, and the voyages of Jesuits to the Kingdom of Siam. ${ }^{102}$

97 On Jews in Padua, see: Malkiel 2014.

98 For more information about the assault on the Padovan Ghetto, see: Heller 2011: 1077.

99 Rosenberg, "Nicolas Guedeville (1652-1719)".

100 N. Guedeville, L'esprit des cours de l'Europe, où L'on voit tout ce qui s'y passe de plus important touchant la politique, et en général ce qu'il y a de plus remarquable dans les nouvelles, The Hague, chez François l'Honoré, Marchand Libraire, dans le Pooten (August 1699): 251.

101 Ibid.: 313; Krupa 2002: 56.

102 See for example: Considerations politiques et historiques sur l'état present des affaires de l'Europe, Pour le 16. De Janvier 1689, Ville-Franche, chez Jean du Moulin (1689): 402-403, 420 (on Turks), 458-459 (on Siam). 


\section{Conclusion}

To conclude, we see that in the scholarly journals a greater variety of Jews were presented, while in the gazettes it was mostly contemporary Jews that were referred to. In the gazettes the image of the Jews was mostly negative - thieves, prostitutes, and adulterers. This image however partially correlates with the awareness of the Jewish community, at least in Amsterdam, regarding certain negative elements that it had. Yet, it was this negative image that was emphasised rather than the positive one which was promoted by the leaders of the community, especially by the Sephardic Jews. Despite this image, the authors show compassion and understanding towards the difficult position of the Jews who were persecuted just for being Jews, without forgetting of course the role that was attributed to them in relation to Jesus. At the same time, the crimes of the Jews mentioned above were no different from crimes committed by the Christians, which demonstrates that the Jews were not truly regarded as far more corrupt than the locals. Still, by being singled out in the local community, they were marked as different, though no calls for actions against them were made. There is no reference made to other non-Christians in these gazettes.

The image of the Jews presented in the scholarly journals is much different. There are four types of Jews mentioned. The first one is the biblical Jews. Those are the most appropriate and positive Jews of all: loved by God, mostly doing good deeds. They are the example of the chosen people, following God's Word. The second is the Jews of the time of Christ. They are sinners, who do not listen to the voice of God, do not accept Christ and are punished for that by exile, which lasts well into the journal's own time. This view reflects the image of the Jews as promoted by the Catholic Church, as well as by some Reformed theologians, which can be seen as the reason for the negative attitude towards them. The third category is the Jews in exile, contemporary Jews. There are not many references to them, and their image is not clearly delineated, though they are criticised for not sufficiently preserving the Jewish language and traditions. Lastly, the fourth group of Jews are the Jewish rabbis, both medieval and contemporary. The rabbis are presented ambivalently: on the one hand, well-known rabbis are considered to be authorities in biblical studies; on the other hand, rabbis are accused of failing to preserve the meaning of the language and of not interpreting the Bible well enough.

Altogether, as the journals and gazettes that we have examined in this article show, there is almost no sign of open hatred of the Jews. The Jews are seen as a poor nation which has been persecuted for centuries because of their stubbornness, but there is no encouragement to continue the persecution. Indeed, at times we see that the editors and the authors are shocked by anti-Jewish events, and hint that they should stop. If we compare contemporary Jews to two other nations-Turks and Siamese, the first seen as Muslims, and latter being referred to as heathens (i.e., by their religious identity, rather than by their ethinicty) — we see that the first are considered to be equal in their 'humanity', if we can use this word in this context, but evil in their ways, and erroneous in their religious views, though some sympathy is expressed for their sufferings. The other two are treated differently. Finally, the Chinese people, another sort of heathen whose language was claimed to be a dialect of Hebrew, are said to have once possessed 
a religion with one God, which was the true original monotheistic religion. ${ }^{103}$ All in all, it seems that the French periodicals were engaged in debates about contemporary issues and reflect the mood of the society. Their message was rather pacifying, exposing to the reader to various aspects of Jews, Jewish traditions, and ways of life.

\section{BIBLIOGRAPHY}

\section{Primary literature}

Basnage, J. (1706-1707), Histoire des Juifs, depuis Jesus-Christ jusqu'à present, 5 vols., Rotterdam.

Ben Israel, M. (1649-1650), מקוה ישראל, Esto es, Esperança de Israel.

Castell, E. (1669), Lexicon heptaglotton: Hebraicum, Chaldaicum, Syriacum, Samaritanum, London.

Chauvin, E., Nouveau Journal des sçavans.

Crosnier, J. (ed.) (1685a), L'année burlesque ou recueil des pieces, que le Mercure a faites pendant l'Année 1683, Amsterdam, chez le Sincere.

Crosnier, J. (ed.) (1685b), L'année burlesque ou recueil des pieces, que le Mercure a faites pendant l'Année 1684, Amsterdam, chez le Sincere.

De Margaillans, G. (1688), Nouvelle Relation de la Chine, Paris.

Flavius Josephus (2008), Sequel to the History of the Jews, chapter XX, in: The Complete Works of Flavius Josephus, Green Forest.

Goldman, S. (1994), God's Sacred Tongue: Hebrew \& the American Imagination, Chapel Hill.

Histoire critique de la République des Lettres, tant Ancienne que Moderne, vol. 1, Utrecht, Chès Guillaume à Poolsum. 1712.

Kimchi, D. (1919), Shekel Hakodesh, The Holy Shekel: The Metrical Work of Joseph Kimchi, ed. H. Gollancz, London-New York-Oxford.

Le Clerc, J. (1710), Genesis sive Mosis Prophetae, $2^{\text {nd }}$ ed., Amsterdam.

Preyelius, A. (1655), Artificia Hominum, Frankfurt on Main, in $12^{\circ}$.

ילקוט רש"י, קנזס סיטי, 2002

\section{Secondary literature}

Alberti, E. (1876), Allgemeine Deutsche Biographie, online edition: http://www.deutsche-biographie. de/pnd121699331.html?anchor=adb [accessed 9 August 2013].

Appleby, D.J. (2007), Black Bartholomew's Day: Preaching, Polemic and Restoration Nonconformity, Manchester.

Barkley, K., Katznelson, I. (2011), States, Regimes, and Decisions: Why Jews were Expelled from Medieval England and France, Theoretical Sociology (40): 475-503.

Benbassa, E. (1999), The Jews of France: A History from Antiquity to the Present, Princeton.

Blumenkranz, B. (ed.) (1972), Histoire des juifs en France, Toulouse.

Blumenkranz, B., Dahan, G., Kerner, S. (1975), Auters juifs en France médiévale: Leur cuvre imprimé, Toulouse.

Bodian, M. (1997), Hebrews of the Portuguese Nation: Conversos and Community in Early Modern Amsterdam, Bloomington-Indianapolis.

Bots, H., Waquet, F. (1997), La République des Lettres, Paris.

Bots, H. (1997), De 'Journaux de Hollande' en hun functie als forum voor het wetenschappelijk debat tussen de leden van de Republiek der Letteren, Tijdschrift voor Tijdschrifstudies 1(2): 14-21.

Bots, H., Waquet, F. (1994), Commercium Litterarium: La communication dans la République des Lettres, 1600-1750, Amsterdam, Maarsen.

103 "Propositions tirées du livre du Père le Comte", in: Bibliothèque volante ou Élite de pièces fugitives, vol. 4, Amsterdam: chez Daniel Pain (1700): 442-447, here 445-447. 
Bots, H. (1994), Un 'intellectuel' avant la lettre: le journaliste Pierre Bayle (1647-1706): l'actualité religieuse dans les Nouvelles de la République des Lettres (1684-1687), Amsterdam.

Bots, H., Posthumus Meyjes, G.H.M. (eds.) (1986a), The Revocation of the Edict of Nantes and the Dutch Republic, Amsterdam.

Bots, H., Posthumus Meyjes, G.H.M. (eds.) (1986b), La Révocation de l'Édit de Nantes et les Provinces Unies, Amsterdam.

Bots, H., Van Lieshout, L. (1984), Contribution à la connaissance des réseaux d'information au début du XVIII siècle. Henri Basnage de Beauval et sa Correspondance à propos de l' "Histoire des ouvrages des savans" (1687-1709), Amsterdam-Maarssen.

Bots, H. (1976), Henri Basnage de Beauval en de Histoire des ouvrages des savans, 1687-1709, 2 vols., Amsterdam.

Bourdrel, Ph. (1974), Histoire des juifs en France, Paris.

Couperus, M., Samuel Masson (?-1742), in: Dictionnaire des journalistes 1600-1789. Online edition: $\mathrm{http} / / /$ dictionnaire-journalistes.gazettes $18 \mathrm{e} . \mathrm{fr} /$ journaliste/558-samuel-masson [accessed 8 September 2013].

Daubresse, S. (2005), Le parlement de Paris, ou, La voix de la raison: (1559-1589), Geneva.

Deutsch, Y. (2012), Judaism in Christian Eyes: Ethnographic Descriptions of Jews and Judaism in Early Modern Europe, trans. A. Aronsky, Oxford.

Díaz Esteban, F. (ed.) (1990), Abraham Ibn Ezra y su tiempo: actas del simposio internacional: Madrid, Tudela, Toledo, 1-8 febrero 1989 / Abraham Ibn Ezra and His Age: Proceedings of the International Symposium: Madris, Tudela, Toledo, 1-8 February 1989, Madrid.

Doron, P. (2010), Rashi's Torah Commentary: Religious, Philosophical, Ethical and Educational Insights, Northvale.

Eisenberg, R.L. (2008), Sabbatical year, in: Dictionary of Jewish Terms: A Guide to the Language of Judaism, online edition.

Elukin, J. (1992), Jacques Basnage and the History of the Jews: Anti-Catholic Polemic and Historical Allegory in the Republic of Letters, Journal of the History of Ideas 53 (4): 603-630.

Fee, G.D., Hubbard Jr., R.L. (eds.) (2011), The Eerdmans Companion to the Bible, Grand Rapids.

Frijhoff, W. (2003), Uncertain Brotherhood: The Huguenots in the Dutch Republic, in: B. van Ruymbeke, R.J. Sparks (eds.), Memory and Identity: The Huguenots in France and the Atlantic Diaspora, Columbia: 128-171.

Gelderblom, A.-J., De Jong, J.L., Van Vaeck, M. (eds.) (2004), The Low Countries as a Crossroads of Religious Beliefs, Leiden.

Gibbs, G.C. (1975), Some Intellectual and Political Influences of the Huguenot Emigrés in the United Provinces, c. 1680-1730, Bijdragen en Mededelingen betreffende de Geschiedenis der Nederlanden 90: 255-287.

Gillingham, S. (2008), Psalms through the Centuries, Malden-Oxford-Carlton.

Green, M. (2015), The Huguenot Jean Rou (1638-1711): Scholar, Educator, Civil Servant, Paris.

Greengrass, M. (1985), Protestant exiles and their assimilation in early modern England, in: Immigrants and Minorities 4: 6-81.

Grell, Ch. (ed.) (1992), La République des Lettres et l'histoire du judaïsme antique: XVI $-X V I I I^{e}$ siècles, Paris.

Heller, M.J. (2011), The Seventeenth Century Hebrew Book, Leiden.

Holmberg, E.J. (2011), Jews in The Early Modern English Imagination: A Scattered Nation, FarnhamBurlington: 11-13.

Huussen Jr., A.H. (2001), Legislation on the Position of the Jews in the Dutch Republic, c. 1590-1796, Tijdschrift voor Rechtsgeschiedenis 43: 43-56.

Israel, J., Salverda R. (eds.) (2002), Dutch Jewry: Its History and Secular Culture (1500-2000), LeidenBoston etc.

Israel, J.I. (1989), The Dutch Republic and its Jews during the Conflict over the Spanish Succession (1699-1715), in: J. Michman (ed.), Dutch Jewish History: Proceedings of the Fourth Symposium 
on the History of the Jews in the Netherlands 7-10 December - Tel Aviv-Jerusalem, 1986, vol. 2, Assen-Maastricht: 117-136.

Jouanna, A. (2015), The Saint Bartholomew's Day Massacre: The Mysteries of a Crime of State, Manchester.

Journal Littéraire, vol. 1, The Hague (May-June 1713): 160-172.

Kaplan, Y. (2001), Gente Política: The Portuguese Jews of Amsterdam Vis-à-Vis Dutch Society, in: Ch. Brasz, Y. Kaplan (eds.), Dutch Jews as Perceived by Themselves and by Others: Proceedings of the Eighth International Symposium on the History of the Jews in the Netherlands, Leiden-BostonCologne: 21-40.

Kaplan, Y. (ed.) (2008), The Dutch Intersection: The Jews and the Netherlands in Modern History, Leiden-Boston.

Kaplan, Y. (1989), The Portuguese Community in $17^{\text {th }}$-century Amsterdam and the Ashkenazi World, in: J. Michman (ed.), Dutch Jewish History: Proceedings of the Fourth Symposium on the History of the Jews in the Netherlands 7-10 December - Tel Aviv-Jerusalem, 1986, vol. 2, Assen-Maastricht: 23-46.

Kaplan, Y., Méchoulan, H., Popkin, R.H. (1989), Menasseh Ben Israel and His World, Leiden-New York.

Kearney, J. (2010), Rashi - Linguist despite Himself: A Study of the Linguistic Dimension of Rabbi Solomon Yishaqi's Commentary on Deuteronomy, New York.

Kingdon, R.M. (1988), Myths about the St. Bartholomew's Day Massacres, 1572-1576, Cambridge, MA.

Krupa, J. (2002), Parliamentary Acts Concerning the Jews in the Polish Commonwealth during the Reign of King Augustus II the Strong (1697-1733), Scripta Judaica Cracoviensia, Cracow (1): 53-63.

Labrousse, E. (1985), «Une foi, une loi, un roi »?: Essai sur la Révocation de l'Édit de Nantes, Geneva.

Le Comte, L. (1696), Lettre à Monseigneur l'Archeveque Duc de Rheims, premier Pair de France. De la langue, des characterés, des livres, de la morale de Chinois, Nouveaux Mémoires sur l'état present de la Chine 1, 367-438.

Littleton, C.G.D. (2005), Ancient Languages and New Science. The Levant in the Intellectual Life of Robert Boyle, in: A. Hamilton, M.H. van den Boogert, B. Westerweel (eds.), The Republic of Letters and the Levant, Leiden: 151-172.

Magdalene, M., Von Thadden, R. (1985), Le refuge Huguenot, Paris.

Malkiel, D. (2014), Stones Speak - Hebrew Tombstones from Padua, 1529-1862, Leiden.

Marshall, J. (2006), John Locke, Toleration and Early Enlightenment Culture, Cambridge-New York.

Mentzer, R.A., Spicer, A. (eds.) (2002), Society and Culture in the Huguenot World 1559-1685, Cambridge.

Norris, H.T. (1994), Edmund Castell (1606-1686) and his Lexicon Heptaglotton (1669), in: G.A. Russel (ed.), The 'Arabick' Interest of the Natural Philosophers in Seventeenth-Century England, Leiden: 70-87.

Parker, Ch.H. (2008), Faith on the Margins: Catholics and Catholicism in the Dutch Golden Age, Cambridge, MA.

Pater, C.A. (1987), Calvin, the Jews and the Judaic Legacy, in: E.J. Furcha (ed.), In Honor of John Calvin, 1509-1564, Papers from the 1986 International Calvin Symposium McGill University, Montreal: 256-295.

Popkin, R.H. (1989), The Rise and Fall of the Jewish-Indian Theory, in: Y. Kaplan, H. Méchoulan, R.H. Popkin (eds.), Menasseh Ben Israel and his World, Leiden: 63-82.

Popkin, R.H. (1987), Isaac La Peyrère (1596-1676): His Life, Work and Influence, Leiden.

Porter, D. (2001), Ideographia: The Chinese Cipher in Early Modern Europe, Stanford.

Rosenberg, A., Nicolas Guedeville (1652-1719), in: Dictionnaire des journalistes (1600-1789), online edition: http://dictionnaire-journalistes.gazettes18e.fr/journaliste/375-nicolas-gueudeville [accessed 24 September 2013]. 
Sela, S. (2003), Abraham Ibn Ezra and the Rise of Medieval Hebrew Science, Leiden.

Sgard, J., Jean Crosnier (?-1709), in: Dictionnaire des journalistes, online edition, http://dictionnairejournalistes.gazettes18e.fr/journaliste/206-jean-crosnier [accessed 18 September 2013].

Shelford, A.G. (2007), Transforming the Republic of Letters: Pierre-Daniel Huet and European Intellectual Life (1650-1720), Rochester, NY-Woodbridge.

Silvera, M. (1991), Contribution à l'examen des sources de L'Histoire des Juifs de Jacques Basnage: Las Excelencias de los Hebreos de Ysaac Cardoso, Studia Rosenthaliana 25 (1): 42-53, and Studia Rosenthaliana 25 (2): 149-161.

Sorkin, D. (2010), Beyond the East-West Divide: Rethinking the Narrative of the Jews' Political Status in Europe, 1600-1750, Jewish History (24): 247-256.

Sutcliffe, A., Karp, J. (eds.) (2011), Philosemitism in History, Cambridge.

Swetschinski, D. (2000), Reluctant Cosmopolitans: The Portuguese Jews of Seventeenth-Century Amsterdam, London.

Xervits, G.G. (ed.) (2015), Religion and Female Body in Ancient Judaism and Its Environments, BerlinBoston.

Ulbricht, O. (1995), Criminality and Punishment of the Jews in the Early Modern Period, in: R. Po-Chia Hsia, H. Lehmann (eds.), In and Out of the Ghetto: Jewish-Gentile Relations in Late Medieval and Early Modern Germany, Cambridge-New York-Melbourne: 49-70.

Van Arkel, D. (2009), The Drawing of the Mark of Cain: A Socio-historical Analysis of the Growth of Anti-Jewish Stereotypes, Amsterdam.

Van de Pol, L.C. (2001), Amsterdam Jews and Amsterdam Prostitution, 1650-1750, in: Ch. Brasz, Y. Kaplan (eds.), Dutch Jews as Perceived by Themselves and by Others: Proceedings of the Eighth International Symposium on the History of the Jews in the Netherlands, Leiden-Boston-Cologne: 173-186.

Van der Linden, D. (2015), Experiencing Exile: Huguenot Refugees in the Dutch Republic, 1680-1700, Farnham.

Vanderspoel, J. (1995), Themistius and the Imperial Court: Oratory, Civic Duty, and Paideia from Constantinus to Theodosius, Ann Arbor.

Van Rooden, P. (2002), Jews and Religious Toleration in the Dutch Republic, in: R. Po-Chia Hsia, H.F.K. van Nierop (eds.), Calvinism and Religious Toleration in the Dutch Golden Age, Cambridge-New York-Melbourne, etc.: 132-147.

Wasserfall, R.R. (ed.) (1999), Women and Water: Menstruation in Jewish Life and Law, HannoverLondon.

Yardeni, M. (2008), Huguenots et Juifs, Paris.

Yardeni, M. (2002), Le refuge huguenot: Assimilation et culture, Paris.

Yardeni, M. (1997), Millénarismes protestants et tolérance des Juifs en France au XVII siècle, Homo Religiosus. Autour de Jean Delumeau, Paris: 658-664.

Yardeni, M. (1990), Anti-Jewish Mentalities in Early Modern Europe, Lanham, MD.

Yardeni, M. (1985), Le refuge protestant, Paris.

Yardeni, M. (ed.) (1980), Les Juifs dans l'histoire de France, Leiden.

Yardeni, M. (1977), New Concepts of post-Commonwealth Jewish History in the Early Enlightenment: Bayle and Basnage, European Studies Review 8: 245-258.

Yardeni, M. (1971), La religion de la Peyrère et le "Rappel des Juifs", Revue d'Histoire et de Philosophie religieuse 51: 245-259. 